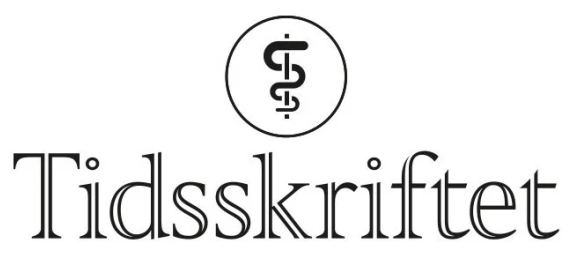

DEN NORSKE LEGEFORENING

\title{
Hjerneblødning som metafor
}

DEBATT

KASHIF WAQAR FAIZ

kashiffaiz@gmail.com

Kashif Waqar Faiz er ph.d., spesialist i nevrologi og master i helseadministrasjon.

Forfatteren har fylt ut ICMJE-skjemaet og oppgir ingen interessekonflikter.

\section{Dårlige valg og ubesluttsomhet er ikke vanlige symptomer på hjerneslag.}

I 2014 skrev jeg en artikkel i Tidsskriftets språkspalte om fotballtrener Tom Nordlie, som etter å ha tapt en fotballkamp sa at «tre hjerneblødninger senket oss» (11). Hjerneblødning ble brukt som en metafor for dårlig forsvarsspill.

Artikkelen fra 2014 har blitt aktuell igjen etter Norges landskamp i fotball mot Tyrkia 8.10.2021. Om foranledningen til baklengsmålet uttalte landslagssjef Ståle Solbakken etter kampen at det var «hjerneblødning av Birger Meling å spille opp på markert midtstopper» (2). Det skal sies at Solbakken i etterkant har tatt selvkritikk og sagt at hjerneblødning var feil $\operatorname{ord}(3)$.

Det er ikke første gang landslagssjefen bruker ordet hjerneblødning om en feil på fotballbanen. Da han i mai uttalte seg om Kristian Thorstvedts røde kort i den første VMkvalifiseringskampen mot Tyrkia i slutten av mars, omtalte han taklingen som førte til det røde kortet, som hjerneblødning (4). Som trener for FC København ble han i 2009 spurt hvorfor han byttet ut spilleren Peter Larsson i pausen, og svarte: «Han fikk en liten hjerneblødning før pausen, og når han løper rundt med et lyserødt kort og samtidig er en tøff duellspiller, er det for risikabelt å ha han på banen» (5).

\section{"Ved bruk av medisinske metaforer kan det vare nyttig å ha noe bakgrunnskunnskap om metaforen man velger»}

Det er ikke kun Ståle Solbakken som bruker hjerneslagmetaforer i beskrivelser av feil på fotballbanen. 18. juli i år tapte Vålerenga mot Haugesund, og etter kampen uttalte Vålerengas spiller Fredrik Oldrup Jensen: «Vi har ti minutter med hjerneblødning, hvor vi slipper inn på kontringer. Da er det tungt» (므). Dagen før tapte Viking mot Odd. Vikings trener Morten Jensen uttalte: «Kollektivt forsvarte vi oss helt ok i store deler av kampen. Men det var noen personlige feil og hjerneblødninger som vi ble kolossalt straffet for» (7.). Sannsynligvis finnes det flere eksempler også. 
Det er forståelig at fotballtrenere og andre har behov for å krydre språket når de beskriver ulike hendelsesforløp, men ved bruk av medisinske metaforer kan det være nyttig å ha noe bakgrunnskunnskap om metaforen man velger. En hjerneblødning, dvs. en intracerebral blødning, er svært sjelden (i praksis aldri) en forbigående hendelse hvor det svartner til for pasienten i noen sekunder eller minutter før vedkommende er tilbake i sin

habitualtilstand. Som oftest dreier det seg om alvorlige symptomer som nedsatt bevissthet, hemiparese, endret sensibilitet, synsforstyrrelser, afasi og andre kognitive symptomer. En subaraknoidalblødning er også en svært alvorlig tilstand med høy grad av funksjonstap som konsekvens. For pasienter med gjennomgått hjerneblødning kan slik metaforbruk oppleves som bagatelliserende. Det er tross alt snakk om noe helt annet enn noen sekunders ubesluttsomhet på en fotballbane.

Tips til fotballfolket: Om dere mener at dere er nødt til å bruke hjerneslagmetaforer i fotballsammenheng, kan dere heller bruke andre metaforer som passer bedre med det dere prøver å beskrive. Ett forslag er drypp ( $\underline{8})$, som er forbigående nevrologiske symptomer av noen minutter til timers varighet. Et annet er blackout, som er kortvarig og forbigående bevissthetstap. Da slipper dere å drible dere vekk.

\section{LITTERATUR}

1. Faiz KW. Hjernetomt om hjerneblødning. Tidsskr Nor Legeforen 2014; 134: 2302. [PubMed] [CrossRef]

2. Gussiås DN, Arntzen M. Solbakken hyller leder lederstjernen: Han tok tak i det. VG 10.10.2021. https://www.vg.no/sport/fotball/i/rEdvgo/solbakken-hyller-ledestjernen-han-tok-tak-idet Lest 11.10.2021.

3. Sande E, Tombra F. Solbakken om hjerneblødning-kommentar: - Noen ganger går jeg over streken. NRK 10.10.2021. https://www.nrk.no/sport/solbakken-om-hjerneblodning-kommentar_-_-noenganger-gar-jeg-over-streken-1.15683481 Lest 11.10.2021.

4. Richvoldsen A. Formspilleren Thorstvedt advares av Solbakken:- Han vet hva jeg tenker om det. Nettavisen 28.5.2021. https://www.nettavisen.no/sport/formspilleren-thorstvedt-advares-av-solbakkenhan-vet-hva-jeg-tenker-om-det/s/12-95-3424132767 Lest 11.10.2021.

5. Veland B. Solbakken om egen spiller: Han var hjerneskadet. Aftenposten 5.10.2009. https://www.aftenposten.no/sport/fotball/i/2Gq8g4/solbakken-om-egen-spiller-ndash-hanvar-hjerneskadet Lest 11.10.2021.

6. Johansen SM. Vålerenga-smell etter snuoperasjon:-Ti minutter med hjerneblødning. Aftenposten 18.7.2021. https://www.aftenposten.no/sport/fotball/i/GQOB3x/vaalerenga-smell-etter-snuoperasjon-timinutter-med-hjernebloedning Lest 11.10.2021.

7. Nye forsvarsfeil felte Viking:- Ikke sett verre forsvarsspill i Eliteserien. Stavanger Aftenblad 17.7.2021. https://www.aftenbladet.no/sport/i/4zLrne/nye-forsvarsfeil-felte-viking-ikke-sett-verreforsvarsspill-i-elite Lest 11.10.2021.

8. Faiz KW. Drypp. Tidsskr Nor Legeforen 2019; 139. doi: 10.4045/tidsskr.19.0025. [CrossRef]

Publisert: 13. desember 2021. Tidsskr Nor Legeforen. DOI: 10.4045/tidsskr.21.0732

Mottatt 15.10.2021, godkjent 7.11.2021.

(C) Tidsskrift for Den norske legeforening 2023. Lastet ned fra tidsskriftet.no 26. april 2023. 